\title{
MANAGEMENT OF EARLY CHILD'S CHARACTER DEVELOPMENT THROUGH HABITUATION AND EXEMPLARY IN KINDERGARTEN
}

\author{
Sofiana Utami and Abdul Wafi \\ Tarbiyah faculty, State Islamic Institute of Madura \\ Email: shofiePB@gmail.com and abdulwafi@iainmadura.ac.id
}

\begin{abstract}
Abstrak
Empat permasalahan yang menjadi kajian pokok dalam penelitian ini. Pertama, bagaimana perencanaan pengembangan karakter anak usia dini melalui pembiasaan dan keteladanan di TK. Al-Quran Matsaratul Huda Panempan Pamekasan. Kedua, bagaimana pengorganisasian pengembangan karakter anak usia dini melalui pembiasaan dan keteladanan di TK. Al-Quran Matsaratul Huda Panempan Pamekasan. Ketiga, bagaimana pelaksanaan pengembangan karakter anak usia dini melalui pembiasaan dan keteladanan di TK. Al-Quran Matsaratul Huda Panempan Pamekasan. Keempat, bagaimana evaluasi pengembangan karakter anak usia dini melalui pembiasaan dan keteladanan di TK. Al-Quran Matsaratul Huda Panempan Pamekasan.
\end{abstract}

Kata kunci: Manajemen, karakter, usia dini, metode.

\begin{abstract}
The four problems that become the main study in this study. First, how to plan early child's character development through habituation and exemplary in the Kindergarten of Al-Quran Matsaratul Huda Panempan Pamekasan. Second, how to organize the development of early child's character through habituation and exemplary in the kindergarten of Al-Quran Matsaratul Huda Panempan Pamekasan. Third, how the implementation of early child's character development through habituation and exemplary in the kindergarten of Al-Quran Matsaratul Huda Panempan Pamekasan. Fourth, how to evaluate the character development of the early child through habituation and examplary in the kindergarten of Al-Quran Matsaratul Huda Panempan Pamekasan. It is a qualitative descriptive study where the data collected through field observation, interviews, and documentation. The results showed that developing an early child's character should be well managed. Instilling good habituation for the children and becoming an excellent example of the teachers proved successful in early child's character development.
\end{abstract}

Keywords: Management, character, early children, methods.

\section{INTRODUCTION}

Education is taken as a vital thing in the world because the world needs educated people to build and develop the country. Still, apart from that, the character is much more critical because people nowadays don't only see how high the education or degree he has achieved, but also the character of each person. The educational process in schools is still much concerned with the cognitive and psychomotor aspects rather than the affective; there are still many teachers in every school who only teach so that the formality is seen, 
without teaching how good ethics must be done; therefore, education must be able to establish a generation that can be expected by everyone, namely humans who are reliable, productive and qualified.

This is in line with what Setiawan ${ }^{1}$ said that quality human beings are educated humans who believe and fear God Almighty, have democratic character, and are responsible. Therefore, national education must function optimally as a vehicle for the nation and character development.

It is where character development is essential efforts to develop the character to become a strong person can be carried out through the cultivation of values to achieve maturity through the cultivation of love and compassion. Therefore, the family must become the primary school in the development of the child's character, because the family is the first to take care of the child, practicing its development every day so that the potential that exists in the child develops significantly, including the development of the child's character and personality.

Through education that is built on the basis of the Pancasila philosophy, which is based on the spirit of Bhinneka Tunggal Ika, it is hoped that the Indonesian nation can become a nation that knows its rights and obligations to be able to live side by side, help and respect each other in order as a dignified nation ${ }^{2}$. On the basis of this philosophical view, the implementation of Early Children Education (PAUD) in Indonesia aims to produce Pancasila generations from an early age. A quote from Suyadi on PAUD Management, that early age is the most appropriate time to shape one's character. If at this time, the character of each child is successfully formed, then later in adulthood, he will become a generation with strong character because more than $50 \%$ of the characters are well embedded. The research states that brain development in early childhood (0-6 years) has accelerated the entire adult brain. It shows that all the potential and intelligence, as well as the basics of a person's behavior, have begun to form at that age. Such the importance of the period that early age is often called as the golden age (golden age $)^{3}$

On this basis, it can be concluded that education must be carried out from an early age to create a bright and qualified generation. The only way to get started is to organize an early childhood education institution. It is strengthened in Wiyani's book ${ }^{4}$ about Bina Karakter Anak Usia dini that Character education is an effort to educate children to make decisions wisely and put it into practice in our daily lives that they can make a positive contribution to the environment. In character education, there are three essential ideas, namely (a) the process of transforming values, (b) being developed in personality, and (c) becoming united in behavior".

Thus, the character education is a conscious and planned effort in shaping the personality of early childhood which aims to develop good behavior in everyday life so that strong characters can be realized into their adulthood.

Of the many educational institutions that exist, according to the researcher's view, the most effective way to instill character education is at an early age because at that age,

\footnotetext{
${ }^{1}$ M Hery Yuli Setiawan, Feri Faila Sufa, Pendidikan Karakter Pada Anak Usia Dini Melalui Kegiatan Bercerita, Volume II Nomor 1, (May 2018), 132.

${ }^{2}$ Suyadi, Manajemen PAUD: TPA-KB-TK/RA, (Yogyakarta: Pustaka Pelajar, 2011), 7.

${ }^{3}$ Ibid., 3.

${ }^{4}$ Wiyani, Ardy, Novan. Manajemen PAUD Bermutu. Yogyakarta: Gava Media. 2015.
} 
every child experiences extraordinary development (the golden age). So, it is expected that character education begins to be encouraged from early childhood education, primarily because the development of children at an early age significantly affects the development of subsequent children. It is in line with Zubaeda's opinion in her book, which says that character education has emerged recently after the Indonesian nation's moral degradation. Society tends to value intellectual excellence and neglect emotional, social, and spiritual maturity. Thus, character education should enter the minor realm and start as early as possible so that the next generation is born with a quality and complete personality" 5 .

Instilling the values of character education in an early child means that teachers, in addition to transferring knowledge and training skills, are also expected to educate children with character, culture, and morality. Managing children's character is not enough to be taught through subjects in class, but schools also apply it through habituation or school culture. Habituation and exemplary activities carried out in schools studied by the researcher are not just orders, but teachers provide direct practice or examples to children. Character education is essentially aimed at forming a strong, competitive, noble, moral, tolerant, cooperative, patriotic, dynamically developing, oriented to science and technology, all of which are inspired by faith and piety to God Almighty based on Pancasila.

So, that is the reason why instilling character education from an early age will make children more resilient, creative, independent, and responsible, and have good personalities and morals. It is the primary goal of early childhood character education; Therefore, the role of schools to introduce the education character of an early age because that time is the right time for the children to learn optimally.

\section{METHODOLOGY}

The approach used in this study is a qualitative-descriptive approach; namely, a research approach that seeks to describe a symptom, event, or that is happening now where the researcher takes pictures of the events that occur as the focus of his/her attention and then describes it. ${ }^{6}$

The use of this approach will make it easier for the researcher to describe how to manage children's character development in kindergarten of Al-Quran Matsaratul Huda Panempan Pamekasan, so that it will convey the validity of a data to conclude the problem because the research is face to face with elements that exist in the kindergarten of AlQuran Matsaratul Huda Panempan Pamekasan.

The researcher's presence in the kindergarten of Al-Quran Matsaratul Huda Panempan Pamekasan is a crucial part because it is to obtain the data that the researcher wants. The researcher's presence is needed to observe directly at the research location to support the success of the research activity.

The research location that the researcher chose was very strategic, not far from urban areas so that it could be easily reached and did not require a long time, namely at an educational institution for the Al-Quran Kindergarten of Matsaratul Huda Panempan Pamekasan, which is located on Kangenan street - Gg Pesantren Panempan Pamekasan.

\footnotetext{
${ }^{5}$ Zubaida, Implementasi Pendidikan Karakter Anak Usia Dini, Volume 1 Edisi X, (January, 2016), 125.

${ }^{6}$ Lexi J. Moleong, Metode Penelitian Kualitatif. (Bandung: Remaja Rosdakrya, 2011), 3-4 
The source of data in this study is the subject from which the data was obtained. According to Loflan in Moleong ${ }^{7}$, the sources of data in qualitative research are in the form of words either in the form of writing distributed by researchers or writing through interview procedures and the behavior of resource persons who are observed directly by the researcher. So, the data sources in this study are human and non-human. Sources of human data are school leaders or principals, teachers, and related parties. The data was formulated in the form of interview transcripts with notes from field observations. Meanwhile, non-human data sources are documents that contain matters relating to the management of early childhood character development through habituation and exemplary in Al-Qur'an kindergarten of Matsaratul Huda Panempan Pamekasan.

Data collection procedures used by the researcher are observation, interviews, and documentation. The researcher carries out observations to see phenomena that exist in the field so that the researcher can collect data..

In this study, the researcher analyzed the data with the following stages: (1) Data Reduction; when the researcher started conducting research, they indeed get a lot of data, even relatively diverse and even very complicated. That is why it is necessary to analyze the data through data reduction. The data obtained is then written in the form of reports or detailed data. (2) Data Display (data presentation); It simplifies data from complex to easy to understand. The presentation of this data can be done in the form of tables, graphs, and the like. (3) Drawing conclusions; the initial conclusions which are put forward are still tentative and will change if no substantial evidence is found to support the next stage of data collection. If the conclusions put forward at the initial stage are supported by valid evidence when the researcher returns to the field to collect data, then the conclusions put forward are taken as credible conclusions.

\section{RESULTS AND DISCUSSION}

Character education consists of two words, namely education, and character. These two words have their meaning. Education refers more to the verb, while the character is more to its nature. That is, through the educational process, later a good character can be produced. According to La Hadisi stating that education is a translation of education, from the word educate or in Latin educo. Educo means developing from within; educate; enforce the law of use. ${ }^{8}$.

The word character comes from the Greek, charassein which means to sculpt. In the Poerwadaminta dictionary, the character is defined as disposition, psychological traits, morals, and character distinguishing one person from another. Meanwhile, according to the Indonesian Dictionary, the character is described as innateness, disposition, and habit. Another opinion says that the character means to mark and focus on applying the value of goodness in the form of action or attitude and behavior. One also argues that the character is a person's attitude that is displayed in everyday life. ${ }^{9}$

In this context, the character is closely related to one's personality. Some interpret it as a person's identity. Therefore, the character is someone's disposition, personality, attitude, behavior and morality that can distinguish him from others so that its relationship

\footnotetext{
${ }^{7}$ Lexi J. Moleong. 157

${ }^{8}$ La Hadisi, Pendidikan Karakter Pada Anak Usia Dini, Vol. 8 No. 2, (Juli-Desember 2015), 53.

${ }^{9}$ Farida Hanum, dkk, Pengembangan Karakter Anak, (Malang: Madani Kelompok Intrans Publishing, 2017), 11.
} 
with character education can be interpreted as value education, character education, and morality education that aims to develop students to maintain, realize and spread goodness in everyday life.

Thus, character education is a conscious and planned effort in shaping early childhood personality, which aims to develop good behavior in everyday life so that strong characters can be realized into adulthood.

\section{Functions of Character Education}

Society views education as the inheritance of culture or cultural values, both as skills, expertise from the older generation to the younger generation so that the community can maintain its survival or maintain its personality. From an individual point of view, education means efforts to develop an individual's hidden potential so that it is concretely actualized so that individuals and society can enjoy the results. It is in line with Salahuddin regarding Character Education of Religion-Based Education and National Culture, quoting from Ahmad Fikri, that the functions of character education are: 1). Development: developing the essential potential of students to be careful, think, and behave well; 2). Improvement: strengthening and building the behavior of a multicultural nation to maintain a dignified nation, and 3). Filter: to filter out negative cultures and absorb cultures that are following the cultural values and character of the nation to improve the nation's civilization that is competitive in world relations ${ }^{10}$.

With the explanation above, it can be concluded that the function of character education is aimed at developing children's potential and developing children's behavior, so that character education becomes a bridge to realize these developments.

\section{Character Education Designs}

Kesuma quoted by Binti Maunah in his journal ${ }^{11}$ argued that there are three designs of character education. First is the design of classroom-based character education. This design is based on the relationship between teachers as educators and students as learners in the classroom. The context of character education is the process of classroom community relations in the context of learning. The relationship between the teacher and the learner is not a monologue but a dialogue with many directions. Second is the design of school culture-based character education. This design builds a school culture that can shape students' character with the help of school social institutions so that specific values are formed and internalized in students. The third is the design of community-based character education. In educating, the public and private school communities do not struggle alone. If those three components work together to carry out well, it will form a solid national character."

Thus, from the three designs of character education, teachers can realize the character building and development of early childhood following the situation and conditions and the ability to interact between teachers and students. In addition to the teacher being professional in the process, students can adapt through the three designs and become habits in everyday life.

10 Anas Salahuddin, Irwanto Alkrienciehie, Pendidikan Karakter Pendidikan Berbasis Agama dan Budaya Bangsa, 104-105.

11 Binti Maunah, Implementasi Pendidikan Karakter dalam Pembentukan Kepribadian Holistik Siswa, Tahun V, Nomor 1, (April 2015), 92. 


\section{Character Education Values}

\begin{tabular}{|c|c|c|}
\hline No & $\begin{array}{c}\text { Character } \\
\text { Value }\end{array}$ & Description \\
\hline 1 & Religious & $\begin{array}{l}\text { Obedient attitudes and behavior in carrying out the teachings of the } \\
\text { religion they adhere to, being tolerant of the implementation of } \\
\text { worship of other religions, and living in harmony with adherents of } \\
\text { other religions. }\end{array}$ \\
\hline 2 & Honest & $\begin{array}{l}\text { Behavior based on efforts to make himself a person who can always } \\
\text { be trusted in words, actions, and work. }\end{array}$ \\
\hline 3 & Tolerance & $\begin{array}{l}\text { Attitudes and actions that respect differences in religion, ethnicity, } \\
\text { opinions, attitudes, and actions of others who are different from } \\
\text { themselves. }\end{array}$ \\
\hline 4 & Discipline & $\begin{array}{l}\text { Actions that show orderly behavior and comply with various rules } \\
\text { and regulations }\end{array}$ \\
\hline 5 & Hard work & $\begin{array}{l}\text { Actions that show orderly behavior and comply with various rules } \\
\text { and regulations }\end{array}$ \\
\hline 6 & Creative & $\begin{array}{l}\text { Thinking and doing something to produce a new way or result from } \\
\text { something one already has. }\end{array}$ \\
\hline 7 & Independent & $\begin{array}{l}\text { Attitudes and behaviors that are not easy to depend on others to } \\
\text { complete tasks }\end{array}$ \\
\hline 8 & Democratic & $\begin{array}{l}\text { A way of thinking, behaving, and acting that evaluates the rights } \\
\text { and obligations of himself and others }\end{array}$ \\
\hline 9 & Curiosity & $\begin{array}{l}\text { Attitudes and actions that always seek to find out more deeply and } \\
\text { widely from what they have learned, seen, and heard }\end{array}$ \\
\hline 10 & $\begin{array}{l}\text { Spirit of } \\
\text { nationality }\end{array}$ & $\begin{array}{l}\text { A way of thinking, acting, and having insight that places the } \\
\text { interests of the nation and state above the interests of themselves } \\
\text { and their groups }\end{array}$ \\
\hline 11 & $\begin{array}{l}\text { Loving the } \\
\text { homeland }\end{array}$ & $\begin{array}{l}\text { A way of thinking, acting, and having insight that places the } \\
\text { interests of the nation and state above the interests of themselves } \\
\text { and their groups. }\end{array}$ \\
\hline 12 & $\begin{array}{l}\text { Appreciating } \\
\text { achievements }\end{array}$ & $\begin{array}{l}\text { Attitudes and actions that encourage him to produce something } \\
\text { useful for society, and recognize, and respect the success of others. }\end{array}$ \\
\hline 13 & $\begin{array}{l}\text { Friendly/comm } \\
\text { unicative }\end{array}$ & $\begin{array}{l}\text { Attitudes and actions that encourage him to produce something } \\
\text { useful for society, and recognize, and respect the success of others. }\end{array}$ \\
\hline 14 & Loving peace & $\begin{array}{l}\text { Attitudes and actions that encourage him to produce something } \\
\text { useful for society, and recognize, and respect the success of others }\end{array}$ \\
\hline & Like to read & $\begin{array}{l}\text { The habit of making time to read various readings that provide } \\
\text { virtue for him }\end{array}$ \\
\hline 16 & $\begin{array}{l}\text { Environmental } \\
\text { care }\end{array}$ & $\begin{array}{l}\text { Attitudes and actions that always try to prevent damage to the } \\
\text { surrounding natural environment, and develop efforts to repair the } \\
\text { natural damage that has occurred. }\end{array}$ \\
\hline
\end{tabular}

${ }^{12}$ H.E.Mulyasa, Manajemen PAUD, (Bandung: PT. Remaja Rosdakarya, 2014), 71-72. 


\begin{tabular}{lll}
\hline 17 & Social care & $\begin{array}{l}\text { Attitudes and actions that always want to help others and people in } \\
\text { need }\end{array}$ \\
\hline 18 & Responsible & $\begin{array}{l}\text { The attitude and behavior of a person to carry out his duties and } \\
\text { obligations, which he should do, towards himself, society, the } \\
\text { environment (nature, social and culture), the state and God } \\
\end{array}$ \\
& Almighty.
\end{tabular}

Thus, the 18 character values above can be concluded that these values are very influential on developing children's character, especially children at an early age, so that anyone who plays a role can later socialize and apply these values.

\section{The Role of the Environment in Character Education Family Role}

Education is a shared responsibility between families, schools, communities, or the government. Schools are a form of continuation of education in the family because the first and foremost education obtained by children is in the family. According to Sayyidina Ali bin Abi Talib (RA) in Subianto's journal that the principal friend of the Prophet Muhammad (SAW) recommended: (a) Invite children from birth to seven years to play, (b) teach children rules of courtesy when they are seven to fourteen years old, (c) at the age of fourteen to twenty-one years, make children as partners of their parents. ${ }^{13}$

So, family participation is an essential role in how children develop from an early age because, at that time, only the family environment could help prepare children's personalities before entering the real level of education. Even Sayyidina Ali instructed parents to make their children develop their potential both in playing and being their partners when they enter adolescence. The parents are obliged to carry out these orders because the future of children depends on how their parents were educated when they were small to adults.

\section{School Role}

If in the home or family environment, a child always imitates what people around him do and say, such as calls to parents "Father and Mother", "Brother and Sister", then the child can also do this when he is in the school environment, imitating like his peers calling teachers "Sir and Madam". It shows that the influence of the school is enormous in shaping the mindset and character of children, but this is not something that is easily achieved without any effort. To be a "teacher," as in the illustration above, requires exemplary and consistent behavior that should be imitated.

This is in line with what was stated by Subianto that character building is part of values education through schools is a noble effort that is urgent to be carried out. In fact, if we talk about the future, schools are responsible for producing students who excel in science and technology and identity, character, and personality. The formation of character and character education through schools, thus, cannot be done solely through knowledge learning but is through the cultivation or education of values. ${ }^{14}$

\section{Community Role}

13 Jito Subianto, Peran Keluarga, Sekolah, dan Masyarakat dalam Pembentukan Karakter Berkualitas, Vol. 8, No. 2, (August, 2013), 337.

14 Ibid., 343. 
The community also has a role that is no less important in building the character of the nation's children. In this case, what is meant by the community here is an older person who is "not close," "unknown" "and is not a family member or relatives" with the child but at that time was in the child's environment or saw the child's behavior. These people can set an example, invite, or prohibit the children from doing an action. The wider community environment has a significant influence on instilling aesthetic and ethical values for character building.

Thus, from several environments that play a role in the formation and education of children's character, the most important is the family, because the family is the first to care for and learn about various things; so, parents have an essential role in the growth and development of children, especially in terms of character.

\section{Basic Characters of Early Child}

Maemunah Hasan, cited by Novan Ardy wiyani stated that Early Child Education (ECD) is the level of education before basic education level, which is a development effort aimed at children from birth to age six years which is done through the provision of stimulus education to help growth and development of physical and spiritual side so that children have the readiness to enter further education, which is held on formal, nonformal, and informal channels. ${ }^{15}$

Thus, PAUD is intended for children aged 0-6 years. That is why children aged 06 years are called early childhood children who live early. Early childhood is a very decisive period for the development and further growth of children. It is because early childhood is a golden period in a child's life. Therefore, all parties need to understand the importance of early childhood to optimize the growth and development of children. Thus, the fundamental character that must be formed in early childhood is an independent character and a disciplined character. Even though they are still very young, they are required to have an independent character.

\section{Habituation}

Habituation is practical efforts in the education and training of children. The result of habituation conducted by teachers is the creation of a habit for the students. Habits are certain automatic behaviors, without being initially planned, and being applied without thinking ". The application of habituation in early childhood begins in childhood, and at that time, the child will get used to what is given. The Marimba's opinion reinforces this quoted Fadlillah that habituation is the instilling of skills to do and to say anything so that children love the proper ways. ${ }^{16}$.

Essentially, habituation has more profound implications than instilling the ways to do and say. The level of habituation takes place from the vital period, namely childhood. It should be noted that in vital and early childhood, this formation is only in the form of habituation to regular life and the basics of cleanliness. In the following period (school period), can begin the habit of fasting and having five-time prayer. According to Tafsir cited by Fadlillah in her book stating that the core of habituation is repetition. In attitude development, the habituation method is very effective because it will train good

15 Novan Ardy Wiyani, Bina Karater Anak Usia Dini, (Yogyakarta: Gava Media, 2015), 19.

16 Muhammad Fadlillah \& Lilif Muaifatu Khorida, Pendidikan Karakter Anak Usia Dini, (Yogyakarta: Ar-Ruzz Media, 2017), 174. 
habits in children from an early age. When the teacher enters the class to say salam (greeting), it can be interpreted as an effort of habituation. If students enter the class without saying a greeting, the teacher reminds them that they should say greeting when they enter the room. It is also a way to build the children's habituation from an early age. ${ }^{17}$

During the formation of habituation for an early child, the children should be accustomed to general ethics that must be carried out in daily interactions. It aligns with Sudrajat's opinion ${ }^{18}$, stating that habituation can be done at the school in various ways and involves many aspects such as time discipline, dress code, etiquette, student's treatment to employees, teachers, leaders, and vice versa. Habituation carried out by leaders, teachers, students, and employees, in the discipline of an educational institution is a very strategic step in forming the character.

\section{Exemplary}

It is common for children to imitate the movements and behavior of their parents or the environment around them. What children see and feel will always be followed even though children are not able to choose and understand what is good and what is bad. For children, what makes them happy and exciting is what they will follow. It is in line with Arifin stating that exemplary comes from the word exemplary, which means things that can be imitated. Exemplary can be interpreted as a form of effort made by someone reflected in behavioral attitudes to achieve specific goals. Exemplary in education is an approach or method influential and proven to be the most successful in preparing and shaping, and developing students' potentials. ${ }^{19}$

Exemplary should be interpreted in a broad sense, namely respecting the words, attitudes, and behaviors inherent in the teacher. According to Islahunnisa quoted from Arifin's book ${ }^{20}$,_exemplary means the instilling of morals, etiquette, and good habits that should be taught and accustomed to by providing real examples.

The exemplary method is a way of teaching science by directing an example to children. It has been done by the Prophet Muhammad PBUH as Allah said in Holy Quran surah Al-Ahzab (33) verse 21:

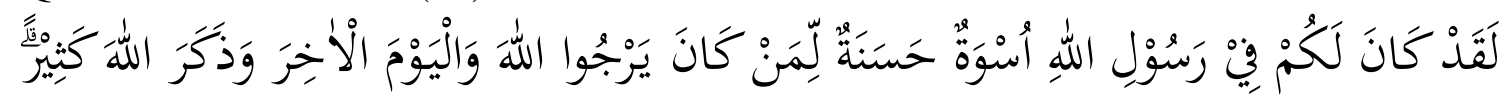

\section{Meaning:}

"Verily there has been in the Messenger of Allah a good role model for you (that is) for those who hope (the mercy of) Allah and (the coming of) the Day of Judgment and He mentions Allah a lot."

It is reinforced by Fadlillah stating that the exemplary method used in the learning process in schools indirectly leads to the competence of the teacher himself because, with a good example, the children will automatically follow the movements of everything that

17 Ibid., 173.

18 Ajat Sudrajat ,Mengapa Pendidikan Karakter?, Tahun I, Nomor 1, (October 2011), 55.

19 Bambang Samsul Arifin, A.Rusdiana, Manajemen Pendidikan Karakter, (Bandung: CV. Pustaka Setia, 2019), 206.

20 Ibid, 207. 
is done and exemplified by the teacher. What they see, hear, and feel will enter the children's memory and then be implemented and developed by them. ${ }^{21}$

Exemplary is the behavior and attitude of teachers and other education personnel in providing examples of good actions so that they are expected to be role models for students to emulate. If teachers and other education personnel want the students to behave following the cultural values and character of the nation, the teachers and other education personnel are the first and foremost to provide examples of behaving in accordance with those values. ${ }^{22}$.

The description above explains that the application of the exemplary method can be made by providing examples for children to do good things in their daily lives. By making good habits on a daily basis, students will do it by themselves, consciously, without any coercion.

From the data display and research findings, it can be discussed four things that are in accordance with the research focus. This discussion is divided into four discussions according to the research focus. Then the researcher also linked based on existing theories. It is intended to explain the results of research findings in the field so that a comprehensive understanding can be obtained. Two main topics of discussion in this study related to the results of the study as it is elaborated in the following discussion:

\section{Planning for Early Childhood Character Development through Habituation and Examplary in Kindergarten of Al-Qur'an, Matsaratul Huda Panempan Pamekasan}

Planning is a process of rational and systemic activity in determining decisions, activities, or steps that will be carried out in the future to achieve goals in an effective and targeted manner. Thus, the initial step of planning in the management of character education development is to process learning as a forum for developing children's character, to instill mutual awareness, and to equalize the perception of the importance of integrating existing values in all activities in school so that those values can become habits by all school stakeholders and the concrete steps that can be taken are to socialize the importance of character education to the early childhood.

Arifin, in his book ${ }^{23}$, states that planning is an essential part of educational success. Planning includes activities to determine what we want to achieve, how to achieve it, how long it takes, the number of people needed, and the cost. Plans were made before an action is performed. It is in accordance with what Maujud stated about the Implementation of Management Functions in Islamic Educational Institutions ${ }^{24}$. He noted that planning is a process of rational and systemic activity in determining decisions, actions, or steps that will be carried out in the future to achieve goals effectively and efficiently. While educational planning is the selection of facts and efforts to relate one fact to another in educational activities, then predicting the

21 Muhammad Fadlillah \& Lilif Muaifatu Khorida, Pendidikan Karakter Anak Usia Dini, 167.

22 Sri Judiani, Implementasi Pendidikan Karakter di Sekolah Dasar Melalui Penguatan Pelaksanaan Kurikulum ,Jurnal Pendidikan dan Kebudayaan, Vol. 16, Edisi Khusus III, (Oktober 2010), 286.

23 Bambang Samsul Arifin, A.Rusdiana, Manajemen Pendidikan Karakter, 24.

24 Fathul Maujud, Implementasi Fungsi-fungsi Manajemen dalam Lembaga Pendidikan Islam, Vol. 14 No. 1, (2018), 33. 
situation and formulating educational actions for the future if needed to achieve the desired results in education".

The meaning of planning as described above implies: First, the manager/leader thinks carefully in advance of the goals and actions based on some methods, plans, or logic and not based on feelings. Second, the plan directs the organization's goals and establishes the best procedures for achieving them. Third, in addition, plans are guidelines for organizations in obtaining and using the resources needed to achieve goals ${ }^{25}$.

Thus, the initial step in the planning of character education management is to instill mutual awareness and equalize the perception of the importance of integrating existing values in all activities in the school so that those values can become a habit by all school stakeholders and the concrete steps that can be taken are to socialize the importance of character education to early childhood. After taking a common perception about the importance of implementing value/character education, schools must translate the school's vision and mission into the character education framework.

In planning requires several stages that will be carried out in the implementation of early childhood character development through habituation and exemplary as well as lesson plans (RPP) and also applying six aspects to children such as Religion and morals, socio-emotional, language and knowledge, cognitive, physical-motor, artskills, then habits and exemplary. Students are also introduced to the natural surroundings, which are packed with natural tadabbur activities, and the last one provides an activity to see to what extent the creativity of students is formed as an activity for children's creativity. There are also tangible results in the form of daily, monthly, and annual documentation and administration, as well as the success of children's development in terms of character, reading the alphabet, the Qur'an. It is reported in the form of report cards.

\section{Organizing Early Childhood Character Development through Habituation and Exemplary in Kindergarten of Al-Qur'an, Matsaratul Huda Panempan Pamekasan}

According to Ramayulis ${ }^{26}$ organizing in education is the process of determining the structure, authority, duties transparently and clearly, and in educational institutions, both individual, group, and institutional. Organizing is defined as the activity of dividing tasks to all parties involved in the field of education.

Based on the description, Maujud argues about the Implementation of Management Functions in Islamic Educational Institutions; He stated that organizing is a process of connecting people involved in a particular organization and integrating tasks and functions within the organization. In the process, a clear division of roles, authorities, and responsibilities is carried out based on their respective sections and fields so that synergistic, cooperative, harmonious, and harmonious working relationships are integrated into achieving the agreed goals. Organizing is essentially a step to determine "who does what" must be clear in an organization. Clarity of individual or group tasks will bring responsibilities. A leader must assign tasks to

25 Maujud, Fathul. Implementasi Fungsi-fungsi Manajemen dalam Lembaga Pendidikan Islam. Jurnal Penelitian KeislamanVol.14 No.1. Fakultas Tarbiyah dan Keguruan UIN Mataram. 2018. 34

26 Bambang Samsul Arifin, A.Rusdiana, Manajemen Pendidikan Karakter, 24. 
people - the right people, following the position and competence, so the job was running or completed as expected quality".

Thus, organizing activities related to character education is not much different from usual learning organizing activities. The most crucial role in receiving authority or duties is the teacher as an agent of instruction in schools. Teachers must be ready to be given tasks and responsibilities in character development in schools, both related to the delivery of material or by example in every step and performance in front of their students.

Organizing is seeking effective relationships between people to work together efficiently and obtain personal satisfaction in carrying out specific tasks under certain environmental conditions to achieve specific goals or objectives. Thus, the most crucial role in receiving authority or duty is the teacher as an agent of instruction in schools. Teachers must be ready to be given tasks and responsibilities in character development in schools, both related to delivering material or providing exemplary in every step and performance in front of their students. Thus, organizing activities related to character education is not much different from usual learning organizing activities. It is the process of determining the structure, authority, and duties transparently. ${ }^{27}$

Organizing early childhood character development through habituation and exemplary is that the principal must know and understand each teacher's character and instill and emphasize unequal character values for students. It is also how to solve problems in different ways. Thus, teachers can have their way of dealing with their students. It also gives freedom to each teacher to deal with students and be more professional in providing assignments to students.

\section{The Implementation of Early Childhood Character Development through Habituation and Examplary in Al-Qur'an Kindergarten of Matsaratul Huda Panempan Pamekasan}

Of the entire series of management processes, implementation (actuating) is the essential management function. The planning and organizing functions are more concerned with abstract aspects of the management process. In contrast, the actuating function is more concerned with activities that are directly related to people in the organization.

This was said by Sista in her journal on the Implementation of Curriculum Management in Improving the Quality of Education ${ }^{28}$. In this case, George R. Terry quoted in Nasution's book argues that actuating is an effort to move group members in such a way that they are willing and trying to achieve the goals of the company and the goals of the company members because the members are also want to achieve these goals. The vital thing to note in this actuating is that an employee will be motivated to do something if he (1) feels confident that he will be able to do it, (2) Convinced that the work is beneficial for him, (3) is not being burdened by personal problems or other

${ }^{27}$ Arifin, Samsul, Bambang, A.Rusdiana. Manajemen Pendidikan Karakter. Bandung: CV. Pustaka Setia. 2019. 24

28 Taufik Rizki Sista, Implementasi Manajemen Kurikulum Dalam Meningkatkan Mutu Pendidikan, Vol. 01, No. 01, (Februari 2017), 32-33. 
tasks that are more important or urgent, (4) The task is a trust for the person who concerned and (5) the relationship between friends in the organization is harmonious."

Thus, in the context of character education, it must always be the basis or reference for all education personnel, especially teachers, that values or characters are not taught in school settings only. The values or characters chosen can only be strengthened and developed according to the conditions and situations surrounding them. Facilitating character development by creating orders, habits, and real examples are implementing real character education

The success of an educational institution is not only determined by the number of natural resources around but is largely determined by the quality of the school's human resources. The character of a child is an important aspect that is the progress of an educational institution. Therefore, quality characters need to be fostered from an early age so that children are accustomed to positive behavior.

The character that is built is expected to encourage every child with their conscience. Considering that character has an essential role in building, character education must be carried out effectively and efficiently. The formation of this character is something that cannot be separated from life. Therefore, it is necessary to have concern from various parties, both from the government, community, schools and especially the family, because the family is the first school for a child. Thus, character education must accompany all aspects of life, including in educational institutions; how the educational institutions can develop children's character through good strategies, habituation, and exemplary in the school environment.

Of the entire series of management processes, implementation (actuating) is the essential management function. The planning and organizing functions are more concerned with abstract aspects of the management process. In contrast, the actuating function is more concerned with directly related activities to people in the organization ${ }^{29}$.

The role played by the school, both principals and teachers of Al-Quran kindergarten of Matsaratul Huda Panempan Pamekasan to build children's character have been running under the vision, mission, and goals of the institution by implementing good habits and being an example for students at school to shape children's character by developing very well. The teacher carries out all activities at school and includes habituation and exemplary; children feel happy if they have carried out disciplinary actions, including children go to school on time; children can obey all school rules by wearing uniforms; children feel happy if they have done honest actions with friends, teachers, and parents; children can feel happy if they have done responsible actions, clean up the plates after eating, throw garbage in its place; children like to do activities by starting with a prayer.

However, those implementations indeed cannot be separated from the obstacles faced by each teacher. However, those obstacles can be overcome in various ways; for example, when students are difficult to be invited to interact with, the teacher then must take action on how the teacher interacts with students more so that students are more comfortable interacting and following the subject. In addition to overcoming

29 Sista Rizki, Taufik. Implementasi Manajemen Kurikulum Dalam Meningkatkan Mutu Pendidikan, Jurnal Educan Vol. 01, No. 01. Universitas Darussalam Gontor. Februari 2017. 32-33 
those obstacles, students are included in tutoring whose abilities are below average, whether it's teaching the Koran or reading. Communication with the Parents directly, and finally, when the classroom teacher cannot handle it, the principal runs it directly.

\section{Evaluation of Early Child's Character Development through Habituation and Examplary in Al-Qur'an Kindergarten of Matsaratul Huda Panempan Pamekasan}

Evaluation is part of the activities of everyday human life. Whether we realize it or not, people often evaluate themselves, their families, the community, the office, and the school environment, as well as the wider environment. ${ }^{30}$.

In this research, both from planning, organizing, and implementing, of course, all of those things require evaluation. Thus, in developing the character of early childhood, it will be known to what extent the optimization and suitability in developing children's character will be known. Thus, the researcher met several respondents to be interviewed and to find out the validity or correctness of the data in the institution. This is true with the existence of an evaluation carried out by the institution, and this is the statement from several respondents about the evaluation that the researcher interviewed.

Kindergarten of Al-qur'an - Matsaratul Huda conducts an evaluation. Among those evaluated is the lesson plan, which is carried out by the teacher and the principal by seeing the suitability of what will be taught. It also utilizes the development of social media to serve as a means of communication both to school principals, teachers especially the parents, to report the results of the child's character development. Then, the teacher council reports at the routine monthly meeting and via face-to-face. The child's character development is also reported to the parents at the regular meeting every three months. Thus, the development of the child's character is known from all parties, and the advantages and disadvantages are known so that the development of the child's character can be produced. ${ }^{31}$.

\section{CONCLUSION}

In this research, both from planning, organizing, and implementing, of course, all of those things require evaluation. Thus, in developing the character of early childhood, it will be known to what extent the optimization and suitability in developing children's character will be known. Thus, the researcher met several respondents to be interviewed and to find out the validity or correctness of the data in the institution. It is true with the existence of an evaluation carried out by the institution, and this is the statement from several respondents about the evaluation that the researcher interviewed.

Kindergarten of Al-qur'an - Matsaratul Huda conducts an evaluation. Among those evaluated is the lesson plan, which is carried out by the teacher and the principal by seeing the suitability of what will be taught. It also utilizes the development of social media to serve as a means of communication both to school principals, teachers especially

30 Salahuddin Anas, Alkrienciehie Irwanto, Pendidikan Karakter Pendidikan Berbasis Agama dan Budaya Bangsa, Bandung: CV. Pustaka Setia. 2013. 263

31 Interview with Ustadzah Hj. Ida Farida as the school principal on Wednesday 18/12/2019 at 08.00am and Ustadzah Subaidah, one of teacher in class A1, kindergarten of Al-qur'an, matsaratul Huda, Panempan on Thursday 19/12/2019 at 09.00am) 
the parents, to report the results of the child's character development. Then, the teacher council reports at the routine monthly meeting and via face-to-face. The child's character development is also reported to the parents at the regular meeting every three months. Thus, the development of the child's character is known from all parties, and the advantages and disadvantages are known so that the development of the child's character can be produced.

\section{REFERENCES}

Arifin, Samsul, Bambang, and A.Rusdiana. Manajemen Pendidikan Karakter. Bandung: CV. Pustaka Setia. 2019.

Fadlilla, Muhammad, Khorida, Mualifatu, and Lilif. Pendidikan Karakter Anak Usia Dini. Yogyakarta: Ar-Ruzz Media. 2017.

Hanum, Farida, dkk. Pengembangan Karakter Anak. Malang: Madani Kelompok Intrans Publishing. 2017.

Judiani, Sri. Implementasi Pendidikan Karakter di Sekolah Dasar Melalui Penguatan Pelaksanaan Kurikulum. Jurnal Pendidikan dan Kebudayaan, Vol. 16, Edisi Khusus III. Oktober 2010.

La Hadisi. Pendidikan Karakter Pada Anak Usia Dini. Jurnal Al-Ta'dib Vol. 8 No. 2, Fakultas Tarbiyah dan Ilmu Keguruan IAIN Kendari. Juli-Desember 2015.

Maujud, Fathul. Implementasi Fungsi-fungsi Manajemen dalam Lembaga Pendidikan Islam. Jurnal Penelitian KeislamanVol.14 No.1. Fakultas Tarbiyah dan Keguruan UIN Mataram. 2018.

Maunah, Binti. Implementasi Pendidikan Karakter dalam Pembentukan Kepribadian Holistik Siswa, Jurnal Pendidikan Karakter, Tahun V, Nomor 1, IAI Tulungagung. April 2015.

Mulyasa, E.. Manajemen PAUD. Bandung: PT. Remaja Rosdakarya. 2014.

Salahuddin Anas, Alkrienciehie Irwanto, Pendidikan Karakter Pendidikan Berbasis Agama dan Budaya Bangsa, Bandung: CV. Pustaka Setia. 2013.

Samsidar, Implementasi Manajemen Kepala Sekolah dalam Penyelenggaraan Pendidikan Islam, Jurnal Fitrah Vol. 01 No. 2 University of Muhammadiyah TapanuliSumatera Utara. Juli - Desember 2015.

Sista Rizki, Taufik. Implementasi Manajemen Kurikulum Dalam Meningkatkan Mutu Pendidikan, Jurnal Educan Vol. 01, No. 01. Universitas Darussalam Gontor. Februari 2017.

Subianto, Jito. Peran Keluarga, Sekolah, dan Masyarakat dalam Pembentukan Karakter Berkualitas, Jurnal Penelitian Pendidikan Islam Vol. 8, No. 2. LPPG: Jawa Tengah. Agustus 2013.

Sudrajat, Ajat. Mengapa Pendidikan Karakter?, Jurnal Pendidikan Karakter, Tahun I, Nomor 1. Yogyakarta: FIS Universitas Negeri. Oktober 2011.

Suyadi, Manajemen PAUD: TPA-KB-TK/RA. Yogyakarta: Pustaka Pelajar. 2011. Wiyani, Ardy, Novan. Manajemen PAUD Bermutu. Yogyakarta: Gava Media. 2015.

Zubaida. Implementasi Pendidikan Karakter Anak Usia Dini. Jurnal Madaniyah. Volume 1 Edisi X, Januari 2016. 